DOI: https://doi.org/10.26661/hst-2019-2-79-10

\title{
THE CONCEPTS OF SECULARIZATION IN THE CONTEXT OF GLOBAL TRANSFORMATIONS OF THE CONTEMPORARY RELIGIOUS LANDSCAPE
}

\author{
(C) DZIUBAK, ROMAN \\ Ivan Franko National University of Lviv (Lviv, Ukraine) \\ E-mail: roman.dziubak@yahoo.com, ORCID iD: https://orcid.org/0000-0002-6321-7739 \\ Ivan Franko National University of Lviv, Universytetska str., 1, Lviv, Ukraine 79000
}

\begin{abstract}
The chosen topic is important because secularization is still considered to be the main trend of the religious dynamics on the Global North which contrasts with the high rates of religiosity on the Global South. In light of the recent research of secularization in the USA presented by D. Voas and M. Chaves the thesis about the correlation between high rates of socioeconomic development and secularization becomes even more significant than it was before. Therefore, there is a need to review this thesis firstly in the light of the results of this new research and secondly in the context of the previous socio-anthropological and sociological understandings of secularization. The goal of this article is to analyze the correlation between socioeconomic development rates and secularization in the context of the global transformations of the contemporary religious landscape. The objectives of this research are: 1) to define the main religious trends of the Global North and the Global South; 2) to analyze the correlation between secularization and modernization in the context of the main sociological theories; 3) to evaluate the existing viewpoints on the correlation between secularization and modernization in the light of the current religious situation of the Global North; 4) to outline the directions for further research of the correlation between high rates of socioeconomic development and secularization.

It is concluded that the contemporary researchers tend to consider the correlation between socio-economic development and secularization not as some kind of a social low that inevitably brings the same result - secular society, but as a tendency, that can be influenced by many other factors and even can be superseded by the opposite process - desecularization. It is also noted that further investigations of the reasons and nature of secularization require a comprehensive approach which, firstly, would consider religious decline trend in the developed countries in the light of increasing existential security, secondly, would take into account historical, cultural and religious peculiarities of different countries or regions and thirdly, would take into consideration the dialectical interaction of secular and religious actors.
\end{abstract}

Keywords: secularization, de-Christianization, Christianity, modernization, comprehensive approach.

Постановка проблеми $\mathbf{y}$ напрямки релігійних векторів. загальному вигляді та її зв'язок із Якщо країни Глобальної Півночі, важливими науковими чи які історично були осередками практичними завданнями. християнства сьогодні все частіше

Актуальність дослідження зумовлена кількома причинами. В країнах Глобальної Півночі та Глобального Півдня спостерігаються протилежні характеризуються як постхристиянські, а основною тенденцією є секуляризація, то в країнах Глобального Півдня, де християнство ще донедавна було

Концепції секуляризації на тлі глобальних трансформацій релігійного ландшафту сучасності 
меншістю, воно набуває сьогодні все більшого поширення. Контраст між високими показниками релігійності в країнах, що розвиваються та тенденцією до зниження цих показників в економічно розвинених країнах відсилає нас до класичного питання соціології релігії про взаємозв'язок модернізації та секуляризації, який був сформульований ще у працях М. Вебера, Ф. Тьонніса, Е. Дюркгайма, К. Маркса та обгрунтовувався надалі у соціологічних теоріях секуляризації шістдесятих сімдесятих років $\mathrm{XX}$ століття. Однак, якщо наприкінці XX - початку XXI століття все більша кількість дослідників почала схилятись до твердження, про те, що модернізація не $\epsilon$ основною причиною секуляризації, але вирішальним чинником $\epsilon$ наявність чи відсутність релігійного плюралізму, то результати недавнього дослідження Д. Воаза та М. Чавеса під назвою "Чи Сполучені Штати є контрприкладом до теорії секуляризації?" знову актуалізують тезу про кореляцію між високими показниками соціальноекономічного розвитку та секуляризацією, що викликає потребу іiі перегляду з одного боку у світлі нових фактів, а 3 іншого в контексті вже наявних соціальноантропологічних та соціологічних способів осмислення секуляризації. Також зазначимо, що результати даного дослідження Д. Воаза та M. Чавеса майже не потрапляли в поле зору українських вчених, що зумовлює потребу заповнювати цю прогалину у вітчизняних дослідженнях секуляризації.

Мета та формування цілей статті (постановка завдання).

Метою статті $\epsilon$ аналіз кореляції між показниками соціальноекономічного розвитку та секуляризацією у контексті глобальних трансформацій релігійного ландшафту сучасності.

Для досягнення мети були поставлені такі завдання:

- розглянути основні релігійні тенденції Глобальної Півночі та Глобального Півдня;

- проаналізувати відношення між секуляризацією та модернізацією в контексті основних соціологічних теорій релігійної динаміки;

- оцінити різні погляди на взаємозв'язок секуляризації та модернізації на тлі глобальної релігійної ситуації сьогодення;

- окреслити напрями подальших теоретичних розробок теми відношення між показниками соціально-економічного розвитку та секуляризації.

Наукова новизна дослідження полягає тому, що вперше у вітчизняній науці зроблена спроба аналізу результатів дослідження Д. Воаза та М. Чавеса під назвою "Чи Сполучені Штати $є$ контрприкладом до теорії секуляризації?” в контексті дискурсу на тему секуляризації. Показано вплив результатів цього дослідження на сучасний науковий дискурс на тему секуляризації.

Аналіз останніх досліджень i публікацій, 3 яких започатковано 
розв'язання даної проблеми і на які спирається автор.

Керуючись поставленою метою, ми здійснюємо наш аналіз на основі напрацювань низки західних дослідників, серед яких П. Норріс, Р. Інглгард, Д. Мартін, Д. Воаз та М. Чавес. Також ми звертаємось до розвідок таких вчених близького зарубіжжя як Д. А. Узланер та Є. А. Стєпанова. Серед вітчизняних дослідників різні аспекти відношення модернізації та секуляризації у своїх працях розглядають Ю. Ю. Медвєдєва, У. І. Лущ, Р. Х. Халіков, І. В. Горохолінська, В. С. Левицький, І. В. Бовгиря, А. Ю. Долгочуб, М. В. Туленков, С. С. Яремчук та К. І. Швалагіна. Зокрема відзначимо розвідку М. В. Туленкова та С. С. Яремчука під назвою "Феномен секуляризації в сучасному соціологічному дискурсі"[3] у якій дані автори, розглядаючи трансформації досліджень секуляризації на прикладі праць С. Брюса, П. Бергера і Д. Мартіна, наголошують на тому, що все менша кількість сучасних дослідників вбачають в модернізації основну причину секуляризації [3, с. 175]. Подібний висновок робить у своїй дисертації I. В. Горохолінська, зазначаючи, що "модернізація чи урбанізація наразі уже не $\epsilon$ визначальними чинниками, котрі впливають на стан релігійної ідентичності" [4, с. 416]. Зауважимо, що загалом українські дослідники у своїх працях приділяють належну увагу соціологічному дискурсу на тему секуляризації та виділяють зміни переважаючих тенденцій у розумінні відношення "модернізація - секуляризація". Однак, у поле зору вітчизняних дослідників майже не потрапляло вже згадане дослідження Д. Воаза та М. Чавеса під назвою "Чи Сполучені контрприкладом до теорії секуляризації?, яке було опубліковане у 2016 році. У цій статті вчені наводять дані стосовно перебігу секуляризації у США, країні, яка протягом тривалого часу була основним контрприкладом до тези про те, що модернізація 3 необхідністю викликає секуляризацію. Результати розвідки Д. Воаза та М. Чавеса знову актуалізують тему взаємозв'язку модернізації та секуляризації у зв'язку 3 чим постає потреба розгляду результатів даного дослідження у контексті дискурсу на тему секуляризації.

Виклад основного матеріалу дослідження 3 обгрунтуванням отриманих наукових результатів.

Аналізуючи стан християнства в глобальному масштабі, сьогодні дослідники часто оперують поняттями Глобальної Півночі та Глобального Півдня. Хоча дана дихотомія базується перш за все на показниках соціально-економічного розвитку країн, вона також наближено окреслює регіони, які протягом тривалого часу були основними осередками християнства. Так, зазвичай, до Глобальної Півночі зараховують

Концепції секуляризації на тлі глобальних трансформацій релігійного ландшафту сучасності 
країни Свропи, США, Канаду, Австралію, Нову Зеландію, а також Японію. Хоча географічний чинник $\epsilon$ присутнім у цьому розподілі, все ж він не $є$ конститутивним, оскільки першочергове значення мають саме соціально-економічні показники. До Глобального Півдня відповідно зараховують решту країн, для яких характерні нижчі показники соціально-економічного розвитку.

За приблизними оцінками американського дослідницького центру "Рew research center", що були опубліковані у 2011 році кількість християн, що проживають в країнах Глобальної Півночі за одне століття перевищила їхню кількість на Глобальному Півдні. Якщо в 1910 році кількість християн в країнах Глобальної Півночі орієнтовно в чотири рази перевищувала їхню кількість на Глобальному Півдні, то століття по тому, станом на 2010 рік частка християн на території Глобальної Півночі склала всього 39\%. Решта християн, частка яких складала відповідно 61\%, проживають на території Глобального Півдня [6]. Таким чином, коли сьогодні Західні країни все частіше характеризуються як постхристиянські, християнство активно розповсюджується на південний схід. Зокрема євангельське християнство, п’ятидесятництво та харизматичні рухи поширюються в країнах Африки, що знаходяться на південь від Сахари та в АзійськоТихоокеанському регіоні. У зв'язку 3 такою динамікою сьогодні дослідники констатують зміщення центру тяжіння християнського світу з Півночі на Південь [7, с. 2], a початок XXI століття інколи характеризують як час розквіту саме Південного християнства. Вчені виділяють низку причин такої трансформації, серед яких не останнє місце займає демографічний аспект даного питання [7, с. 79-89]. Окрім цього, вагомим фактором також $\epsilon$ протилежні напрямки релігійних векторів даних регіонів. В розвинених країнах спостерігається статистичне зниження показника християнської ідентичності, коли в країнах, що розвиваються цей показник зростає. Інакше кажучи, коли в країнах Глобальної Півночі, які протягом століть були осередками християнства сьогодні спостерігається тенденція до дехристиянізації, то у вищезгаданих регіонах Глобального Півдня, де християнство не було поширеним, населення навпаки християнізується.

Водночас в країнах Глобальної Півночі відбувається зниження показників не лише пов'язаних 3 християнством, але тих, що стосуються релігійності загалом. На противагу цьому в країнах Глобального Півдня показники релігійності населення залишаються високими. Отже, неминуче виникає запитання про відношення між високими показниками соціальноекономічного розвитку та секуляризацією, активні дискусії щодо якого не вщухають 
починаючи 3 шістдесятих років XX століття, відколи дослідники звернулися до активного вивчення секуляризації аж по сьогодні.

Протягом цього часу були сформовані кілька способів теоретичного осмислення секуляризації. Ще у працях класиків соціологічної науки у тій чи іншій формі висловлювалась точка зору, згідно 3 якою секуляризація $\epsilon$ наслідком суспільного прогресу. Цю тезу згодом поглиблювали та обгрунтовували у своїх працях дослідники протягом шістдесятих сімдесятих років $\mathrm{XX}$ століття, розглядаючи секуляризацію як наслідок модернізаційних трансформацій. Сукупність праць цього періоду пізніше була виокремлена в окрему парадигму вивчення секуляризації. На противагу цій парадигмі протягом дев'яностих років XX століття була сформована теорія релігійної економіки, в рамках якої секуляризація, яка найбільше проявилась в країнах Західної Європи, не пов'язувалась 3 модернізацією, але розглядалась як наслідок тривалої церковної монополії, яка не змогла вдало пристосуватись до конкурентних умов плюралізму, що призвело врешті решт до зниження запиту на релігійну пропозицію.

Дискусія між прибічниками обох теорій, що почалась наприкінці XX та продовжилась у XXI столітті не вщухає i дотепер. Як ми можемо бачити, соціологи у різний спосіб відповідали на питання чи секуляризація $\epsilon$ наслідком суспільного розвитку. У різний час, переважаюча частина соціологічної спільноти схилялась до різних варіантів відповіді. Якщо до появи теорії релігійної економіки, соціологи у своій більшості схилялись до тези про причинно-наслідковий зв'язок між модернізацією та секуляризацією, то з часу появи цієї альтернативної теорії все більша кількість соціологів почали схилятись до твердження, згідно 3 яким сама по собі модернізація не призводить ні до занепаду релігіi, ні до іiі процвітання, але визначальним фактором $\epsilon$ наявність чи відсутність у суспільстві релігійного плюралізму. Поступово, основною перспективою у соціологічному мейнстримі стала теорія релігійної економіки. Однак, дискусія на цьому не припинилась. Сучасні прихильники погляду про взаємозв’язок модернізації та секуляризації продовжують обгрунтовувати його на основі нових соціологічних досліджень, що може спонукати соціологічну спільноту ще раз переглянути питання про причини секуляризації у світлі нових фактів. Зважаючи на дискусивний характер соціологічного дискурсу на тему секуляризації, спробуймо поглянути на глобальний релігійний ландшафт сьогодення крізь призму теорій, що сформувалися у рамках соціологічної науки. 3 цією метою, розгляньмо основні тези даних теорій, а також альтернативні

Концепції секуляризації на тлі глобальних трансформацій релігійного ландшафту сучасності 
способи осмислення секуляризації, які виникли в рамках соціології.

Бачення секуляризації, як наслідку прогресу було сформульоване вже в працях таких зачинателів соціології, як М. Вебер, Е. Дюркгайм, Ф. Тьонніс та К. Маркс. Закладена ними основа стала фундаментом для подальших спроб теоретичного осмислення цього процесу. Ідеї класиків соціології стосовно секуляризації знайшли своє продовження $\mathrm{y}$ роботах дослідників шістдесятих років XX століття, найвідомішими серед яких були Б. Вілсон, П. Бергер та Т. Лукман. У їхніх роботах погляд на секуляризацію як наслідок суспільного розвитку був сформульований у формі тези про те, що секуляризація $\epsilon$ обов'язковим наслідком модернізації. Це твердження стало основоположним для переважної більшості соціологічних праць шістдесятих - сімдесятих років. Серед модернізаційних процесів, які виокремлювались дослідниками в якості таких, що сприяють секуляризації були раціоналізація, індустріалізація та урбанізація. Між модернізаційними процесами та секуляризацією встановлювалось прямопропорційне відношення. Вважалося, що чим більше суспільство модернізується, тим більше світським воно стає i навпаки, чим менш модернізованим $\epsilon$ суспільство - тим вищий рівень його релігійності.

Секуляризація розглядалась в теоріях цього періоду на кількох рівнях. Окрім секуляризації в значенні зниження релігійності на індивідуальному рівні, дослідники виділяли також секуляризацію у площині соціальних структур, що означало зниження впливу релігії в масштабах суспільства в результаті функціональної диференціації. Тобто, йшлося про те, що в процесі суспільного розвитку виокремились такі сфери людської діяльності, як економіка, політика, наука і т. д. Окремою сферою постала також релігія. Оскільки раніше релігійний інститут поширював свій вплив на всі види людської діяльності, бувши відтепер обмеженим рамками власної суспільної ніші, він втратив свій вплив на інші сфери. Першочергове значення у контексті теорій секуляризації шістдесятих - сімдесятих років XX століття мала секуляризація саме на рівні суспільних структур, а зниження рівня індивідуальної релігійності відповідно розглядалось як похідний процес. Тобто, причина секуляризації на рівні індивідуальної релігійності вбачалася в секуляризації на рівні суспільних структур, яка своєю чергою відбулася в ході модернізації.

Якщо поглянути на сьогоднішню релігійну ситуацію в контексті твердження про прямопропорційну залежність між секуляризацією та модернізацією, то ми помітимо, що серед країн Глобального Півдня, які досі проходять крізь модернізаційні процеси показники релігійності $\epsilon$ високими. 3 огляду на це, принаймні про жорстку взаємозалежність між процесами модернізації та секуляризації 
говорити не доводиться. Подібного висновку дійшли також соціологи у вісімдесятих роках XX століття. На тлі появи релігії на політичній арені різних країн світу, що відбулося наприкінці сімдесятих років $\mathrm{XX}$ століття, вчені переосмислили тезу про занепад індивідуальної релігійності як обов'язковий наслідок секуляризації на рівні суспільних

структур.

Секуляризація, як функціональна диференціація все ще розглядалась в якості обов'язкового наслідку модернізації, однак занепад індивідуальної релігійності почав сприйматися вже як можливий, але не обов'язковий розвиток подій. Майбутне релігії на індивідуальному рівні розглядалося як відкрите, a не детерміноване наперед. До цього переосмислення долучились зокрема такі дослідники як Дж. Лечнер, Н. Луман, М. Чавес, Х. Казанова і Д. Йамейн.

Якщо поглянути на сучасний світ 3 точки зору оновленого варіанту теорії секуляризації, то принаймні в загальних рисах ця теорія не суперечить наявним реаліям. Справді, звуження сфери впливу релігії в результаті функціональної диференціації відбулося у процесі модернізації за нечисленними винятками в усіх країнах. Також, в деяких країнах цей процес макрорівня супроводжувався зниженням індивідуальної релігійності, як це було в Західній Європі, а в деяких показники залишались високими, прикладом чого протягом $\mathrm{XX}$ століття було США. Однак, якщо зв'язок між модернізацією та зниженням рівня індивідуальної релігійності не є обов'язковий, постає питання, чи є правомірним в такому випадку пов'язувати занепад релігії в Європі саме 3 модернізацією? Чи були інші, більш вагомі фактори, які спонукали Європу піти шляхом секуляризації? Відповідно, питання про те, чому в одних обставинах в процесі модернізації населення секуляризується, а в інших ні, залишилося відкритим.

В дев'яностих роках XX століття як альтернатива до тогочасної теорії секуляризації була сформована теорія релігійної економіки, найвідомішими представниками якої $є$ Р. Старк, У. Бейнбридж, Р. Фінк та Л. Яннакон. В рамках теорії релігійної економіки секуляризація на рівні індивідуальної релігійності пов'язується не $з$ модернізаційними процесами, але 3 відсутністю релігійного плюралізму. Так, стрімке зниження показників релігійності в Західній Європі, 3 перспективи теорії релігійної економіки розглядається як наслідок того, що церква, яка довгий час була єдиним наявним релігійним вибором і по суті була монополістом, опинившись в плюралістичних умовах релігійного ринку, не змогла пристосуватись до нових конкурентних умов. В результаті цього вона виявилась нездатною задовільнити наявну релігійну потребу, що в кінцевому підсумку призвело до зниження

Концепції секуляризації на тлі глобальних трансформацій релігійного ландшафту сучасності 
попиту на релігійну пропозицію в цілому.

Якщо теорія секуляризації шістдесятих - сімдесятих років базувалась на основі європейського історичного досвіду, який свідчив про те, що в процесі модернізації європейські країни значною мірою секуляризувалися, то теорія релігійної економіки формувалася на основі історичного досвіду США, де 3 самого початку різні протестантські конфесії знаходились в умовах конкуренції, а високі показники релігійності населення зберігались протягом усього XX століття. Згідно 3 теорією релігійної економіки саме наявність релігійного плюралізму стала запорукою високого рівня релігійності США. Відповідно, його відсутність у Європі в рамках цієї теорії розглядається в якості причини занепаду релігійності в цій частині світу.

Зазначимо, що саме високі показники релігійності у США стали причиною зміни панівних тенденцій у соціологічному мейнстримі. До появи теорії релігійної економіки більшість соціологів схилялась до тези, згідно 3 якою модернізація з необхідністю призводить до секуляризації. Високі показники релігійності США в тогочасній теорії секуляризації або ж не брались до уваги, мовляв релігія в Сполучених штатах по суті секуляризувалась, або ж сприймались в якості певної аномалії, "американської винятковості". У цьому контексті теорія релігійної економіки постала як свого роду реакція на нехтування

показниками

релігійності США з боку тогочасної теорії секуляризації, яка за своєю суттю була європоцентрична. У кінцевому підсумку, приклад США, однієї 3 найбільш модернізованих країн світу, в якій констатувались високі показники індивідуальної релігійності став фактором, який спонукав соціологів переосмислити тезу про те, що модернізація була основною причиною секуляризації.

Якщо поглянути на глобальний релігійний масштаб сучасності, то виникає питання, чи справді рівень індивідуальної релігійності США дотепер залишається стабільно високим? Невже у США не відбувається зниження релігійності населення в XXI столітті? Справді, сьогодні твердження про незмінно високі показники релігійності у США також постає предметом критичного перегляду. Д. Воаз та М. Чавес у своїй статті під назвою "Чи Сполучені Штати $\epsilon$ контрприкладом до теорії секуляризації?” вказують на те, що у Сполучених Штатах Америки також присутнє зниження релігійних показників [9]. Вони зазначають, що у порівнянні 3 іншими країнами рівень релігійності в США залишається високим. Однак, разом 3 тим відбувається "довготривалий спад, що виникає в основному в наслідок зміни поколінь" [9, с. 1548], що є подібним до релігійних змін в інших частинах світу, таких як Канада, Австралія, Нова Зеландія. У висновку автори зазначають, що у світлі наведених ними даних США не може надалі розглядатись 
як приклад модернізованої країни в якій не відбувається зниження релігійності. Д. Воаз та М. Чавес вказують на те, що замість традиційного питання - чому у США не відбувається секуляризація?, треба запитувати про характер іiі перебігу - чому у США вона відбувається саме таким темпом і у такий спосіб? [9, с. 1549].

У цьому контексті варто згадати ще одну теорію, в рамках якої секуляризація так само постає наслідком модернізації, але даний зв'язок обгрунтовуєтеся в інший спосіб, ніж це було зроблено в рамках теорій секуляризації шістдесятих - сімдесятих років. Авторами цієї теорії є П. Норріс та Р. Інглгард. Високий рівень релігійності в країнах що розвиваються та зниження релігійних показників в розвинених країнах вони пов'язують 3 екзистенційною безпекою. П. Норріс та Р. Інглгард вказують на те, що в країнах, які розвиваються рівень екзистенційної безпеки $\epsilon$ нижчим, що викликано економічними чи політичними негараздами. I навпаки, розвинені країни 3 високим рівнем економічного розвитку, стабільною демократією, якісною медициною та дієвою правоохоронною системою забезпечують високий рівень екзистенційної безпеки стосовно власного життя, добробуту сім'ї і т. д. На думку П. Hoppic та Р. Інглгарда, саме особиста занепокоєність, для якої $\epsilon$ більше причин в країнах, що розвиваються спонукає населення звертатися по допомогу, заспокоєння та надію до трансцендентних сил і відповідно рівень релігійності $\epsilon$ високим. I навпаки, оскільки рівень фінансового добробуту та особистої безпеки в розвинених країнах $є$ високим, то відповідно причин звертатися до надприродного є менше. Тобто, релігійність населення в рамках цієї теорії корениться в почутті внутрішньої занепокоєності та саме воно спонукає людей звертатися по допомогу до трансцендентних сил.

У світлі останніх статистичних даних стосовно присутності секуляризаційних тенденцій у США, теорія П. Норріс та Р. Інглгарда постає актуальною, оскільки демонструє причини 3 одного боку тенденцій до секуляризації в розвинених країнах, a 3 іншого пояснює високі показники релігійності в країнах, що розвиваються. По суті, у цій теорії модернізація призводить до секуляризації, однак не безпосередньо, а опосередковано. Модернізація призводить до підвищення рівня особистого комфорту та безпеки, що в результаті призводить до занепаду релігії. Тобто, дана теорія розглядає тенденцію до зниження показників індивідуальної релігійності крізь призму психологічних особливостей, які виявляються у зверненні людей до трансцендентної допомоги в часи скрути та непевності.

Концепції секуляризації на тлі глобальних трансформацій релігійного ландшафту сучасності 
П. Hoppic та Р. Інглгард також зазначають, що у процесі модернізації, а саме при переході від аграрних до індустріальних суспільств відбувається поширення раціонально-світських цінностей. Однак на наступному етапі переходу від індустріальних до постіндустріальних суспільств поширення набувають цінності самовираження i в таких умовах релігія не занепадає, але трансформується. Відбувається перехід від інституційних форм релігійності до індивідуальних духовних пошуків. Отже, у рамках даної теорії, секуляризація на індивідуальному рівні не постає як неминучий результат суспільного поступу, "кінець історії, але може змінитися десекуляризацією, в ході якої поширення набуде індивідуалізована форма релігії.

Теза про екзистенційну безпеку, як причину зниження релігійності населення вдало пояснює наявну тенденцію до зниження показників релігійності в розвинених країнах. Водночас, той факт, що в різних країнах секуляризація відбувалась у різний спосіб і з різними темпами наштовхує на думку про те, що зв'язок між секуляризацією та екзистенційною безпекою необхідно розглядати не як жорстку залежність, але як певну тенденцію, яка відбувається під впливом цілої низки інших факторів, які можуть зумовлювати різні варіанти ii перебігу.

На той факт, що секуляризація у різних країнах приймає різні форми вказував ще у 1978 році британський соціолог Д. Мартін у своїй праці “Загальна теорія секуляризаціï” [8]. У ній він виділяє патерни секуляризації, які даний процес набуває в залежності від особливостей різних країн. На його думку, саме недостатня увага до історичних та релігійних особливостей окремих локальних контекстів була недоліком теорій секуляризації шістдесятих сімдесятих років.

Негативне ставлення до жорсткого підходу у розгляді секуляризації та увага до особливостей локальних контекстів, що були притаманними для праць Д. Мартіна були підхоплені соціологами у XXI столітті. Увагу до даних аспектів також привернула теорія множинних сучасностей (multiple modenities) Ш. Ейзенштадта. Згідно 3 цією теорією, сучасність розглядається як результат з одного боку сукупності історичних, культурних, політичних та релігійних особливостей певної держави чи регіону, а з іншого вона $\epsilon$ наслідком реалізації певних програм сучасності (modernity), які накладаються на особливості локальних контекстів. Як зазначає Д. Узланер, складовими елементами таких програм можуть бути “нова антропологія суб'єкта, капіталістична економіка, національна держава, демократія i права людини, наукова раціональність, світськість" [4, с. 154]. Всі ці елементи, накладаючись на конкретний цивілізаційний, історичний досвід, формують різні варіанти сучасних суспільств. 
В рамках теорії множинних модерностей обов'язкова залежність між модернізацією та секуляризацією не встановлювалася. Першочергове значення у тому, чи суспільство йтиме шляхом стрімкої секуляризації, як це відбулось в країнах Західної Свропи, чи шляхом США, де зниження показників релігійності є повільним та поступовим, чи шляхом, в якому показники релігійності індивідуальної високими залишатимуться особливостей кожної окремої країни чи регіону. Тобто, на основі теорії множинних модерностей майбутнє релігії постає відкритим і лише частково може визначатися суспільними трансформаціями, що відбуваються в процесі модернізації. Однак, першочергове значення мають саме вищезгадані особливості конкретних суспільств. Так, під впливом теорії множинних модерностей акцент у питанні стосовно причин секуляризації Західної Європи змістився 3 факторів соціальноекономічного розвитку до історикокультурних особливостей цього регіону. Д. Узланер з цього приводу зазначив: “Европа $є$ настільки світською не тому, що вона найрозвиненіша, але тому, що в іiі культурі взяли верх світські мотиви французького Просвітництва." [4, с. $175]$.

Зауважмо, що теорія множинних модерностей стала впливовою у соціологічному дискурсі на тему секуляризації у час коли соціологічні дані підтверджували незмінно високі показники індивідуальної релігійності США, що було основним прикладом, який суперечив тезі про те, що модернізація 3 необхідністю призводить до секуляризації. У таких умовах, твердження про те, що саме історико-культурні особливості зумовлюють яким шляхом піде кожна окрема країна, пояснювало відмінність напрямів релігійних векторів Західної Європи та США. Однак, якщо критичні зауваження Д. Воаза та М. Чавеса про секуляризацію у США вірні, то заперечувати наявність зв'язку між модернізацією та секуляризацією сьогодні стає все важче, оскільки основний приклад для спростування цієї тези, стає прикладом на їі підтвердження.

На основі теорії множинних модерностей повноцінна теорія секуляризації так i не була сформована. Однак іiі поява значно вплинула на весь подальший дискурс на тему секуляризації. Теорія множинних модерностей сприяла усвідомленню того, що історичні, культурні та релігійні особливості неминуче впливають на те, чи суспільство секуляризуватиметься і як саме це буде відбуватись. Тому, сьогодні, як прихильники, так i опоненти тези про те, що модернізація $\epsilon$ основною причиною секуляризації зазначають важливість історикокультурних особливостей окремих регіонів для розуміння причин та

Концепції секуляризації на тлі глобальних трансформацій релігійного ландшафту сучасності 
характеру наявних релігійних тенденцій.

У світлі критичних зауважень стосовно наявності секуляризації у США, а також загальної тенденції до зниження релігійності в країнах Глобальної Півночі, у соціологічній дискусії знову набуває актуальності теза про те, що модернізація $\epsilon$ основною причиною секуляризації. Однак, варто зазначити, що сучасні прихильники цієї тези, схильні говорити не про жорсткий зв'язок модернізації та секуляризації, але про тенденції в розвинених країнах до зниження релігійності. Так, Є. А. Степанова коментуючи теорію П. Норріс та Р. Інглгарда зазначає, що “секуляризація радше описується як тенденція, обмежена в просторі та в часі, а не як загальний закон" [2, с. 58].

Так само і Д. Воаз та М. Чавес, констатуючи

довготривалої, наявність секуляризації в США, займають помірковану точку зору стосовно відношення між модернізацією та секуляризацією.

Коментуючи втрату США статусу контрприкладу до тези про те, що модернізація 3 необхідністю викликає секуляризацію, Д. Воаз та М. Чавес зазначили: "Ми не готові стверджувати що усунення цього статусу має саме собою відновити стару ідею, про що модерність всюди в кінцевому рахунку призведе до секуляризації. Однак, ми готові стверджувати, що оскільки більше не є очевидним, що Сполучені Штати перебувають на якісно іншій релігійній траєкторії, ніж Європа, то занадто рано стверджувати, що теорія секуляризації не застосовується за межами Європи, Канади та Австраліі”" [9, с. 1551]. Тобто, дослідники вказують, що вони не стверджують універсальний характер секуляризації, чи іiі неминучість, але зазначають що вона не обмежується вищезазначеними країнами.

Також, сучасні прихильники тези про зв'язок секуляризації та модернізації займають помірковану позицію у своїх прогнозах стосовно змін релігійного ландшафту, оскільки усвідомлюють можливість впливу інших факторів у подальшому розвитку подій. 3 цього приводу Д. Воаз та М. Чавес зазначили:

“Специфічні особливості країни, безумовно, ускладнюють, а мабуть i унеможливлюють впевнений прогноз майбутніх рівнів релігійності в Сполучених Штатах або ще десь, але ми намагаємося встановити соціальну закономірність, а не передбачати майбутне" [9, с. 1550]. Знову таки, йдеться про закономірність, як тенденцію, а не як закон, який 3 обов'язково призводить до одного наслідку.

Тобто, сучасні теоретики секуляризації намагаються уникати детерміністичних перспектив щодо майбутнього релігії, зважаючи на можливий вплив інших факторів, які можуть визначати подальший хід подій. Такими наприклад можуть бути згадані нами в контексті теорії множинних модерностей історичні, культурні та релігійні особливості конкретної 
країни чи регіону, які без сумніву впливають на

трансформацій характер ландшафту.

Ще одним фактором, що може впливати на напрям релігійного вектора суспільства i якому приділяється мабуть недостатня увага в рамках соціологічного дискурсу на тему секуляризації $\epsilon$ поведінка та позиція церков, релігійних організацій та їх членів. Р. Фенн, критикуючи механічний підхід до розгляду секуляризації, у 1978 році зазначив, що “індивіди та групи $є$ відповідальні за секуляризацію: не безособові та абстрактні сили як от технології або освіта, але живі та активні діячі" [5, с. 60].

Однією зі сторін діалектичної взаємодії між секуляризацією та десекуляризацією, світськістю та релігійністю $\epsilon$ церкви, релігійні організації та їхні члени. Саме ці “живі та активні діячі" можуть впливати на зміни рівня індивідуальної релігійності в локальних осередках чи загальносуспільному вимірі.

Разом 3 проповідницькою діяльністю факторами впливу можуть бути відкритість церков до суспільства, публічна позиція стосовно актуальних суспільних питань та готовність церков брати активну участь у викликах, які постають перед суспільством. Інакше кажучи, від того чи церкви $€$ активними учасниками громадянського суспільства сьогодні також залежить вектор яким рухатимуться окремі громади та суспільства завтра.

Висновки дослідження. $\mathrm{y}$ світлі досліджень Д. Воаза та М. Чавеса стосовно перебігу секуляризації у США, теза про те, що модернізація призводить до секуляризації сьогодні знову набуває актуальності.

Однак, на відміну від авторів теорії секуляризації шістдесятих сімдесятих років, сучасні дослідники розглядають цей зв'язок не в якості загального закону, який 3 необхідністю призводить до єдиного результату, але як певну тенденцію, що констатується у суспільствах 3 високими показниками соціальноекономічного розвитку.

Разом 3 констатацією цієї тенденції, дослідники приділяють увагу особливостям конкретних суспільств, що впливають на напрямки релігійного вектору.

3 огляду на історію соціологічного дискурсу, у вирішенні проблеми причин та характеру секуляризації, на нашу думку, існує потреба саме у комплексному підході, який би міг враховувати по-перше, тенденцію до зниження релігійності у розвинених країнах у зв'язку 3 підвищенням екзистенційної безпеки, по друге, зважав би на історичні, культурні та релігійні особливості конкретних регіонів, а по третє, брав до уваги діалектичну взаємодію світських та релігійних дієвців.

Концепції секуляризації на тлі глобальних трансформацій релігійного ландшафту сучасності 


\section{Список використаних джерел}

1. Горохолінська, I. В., 2019. Демаркація секулярного / постсекулярного в сучасній релігійності: філософський та богословський дискурс : дис. ... д-ра філос. наук : 09.00.11; 09.00.14. Київ. 510.

2. Степанова, Е. А., 2009. Теории секуляризации в "проекте модерна": возможности и границы. Научный ежегодник Института философии и права Уральского отделения Российской академии наук. 9. 54-73.

3. Туленков, М. В., Яремчук С.С., 2017. Феномен секуляризації в сучасному соціологічному дискурсі. Соціальні технології: актуальні проблеми теорії та практики. 73. 164-177.

4. Узланер, Д., 2019. Конец религии? История теории секуляризации : монография. Москва : Издательский дом Высшей школы экономики. 240.

5. Fenn, R. K., 1978. Toward a theory of secularization. Norwich : Monograph series Society for the Scientific Study of Religion. 1. 91.

6. Global Christianity - A Reportonthe Sizeand Distributionof the World's Christian Population, 2011. [Electronic resourse] / Pew Research Center: [official website]. Mode of access: https://www.pewforum.org/2011/12/19/global-christianity-exec/

7. Jenkins, P. , 2002. The Next Christendom : The Coming of Global Christianity. New York: Oxford University Press. 270.

8. Martin, D. A., 1978. General Theory of Secularization. Oxford: Blackwell Publishing, 1978. 353.

9. Voas, D., Chaves, M., 2016. Is the United States a Counterexample to the Secularization Thesis? American Journal of Sociology. 121, 5. 1517-1556.

\section{REFERENCES}

1. Horokholinska, I., 2019. The demarcation of the secular / postsecular in modern religiosity: philosophical and theological discourse. (Ph. D. dissertation). National Pedagogical Dragomanov University, Kyiv. 510.

2. Stepanova, E. A., 2009. Secularization theories and the «project of modernity»: possibilities and limits. Nauchnyy ezhegodnik Instituta filosofiii prava Ural'skogo otdeleniya Rossiyskoya akdemii nauk. (Scientific yearbook of the institute of Philosophy and Law of Ural Branch of Russian academy of sciences), 9. 54-73.

3.Tulenkov, M., Yaremchuk, S., 2017. Phenomena of Secularization in Contemporary Discourse. Sotsialni tekhnolohii: aktualni problemy teorii ta praktyky. (Social technologies: actual issues of theory and practice), 73. 164-177.

26. Uzlaner, D., 2019. The End of Religion? A History of the Theory of Secularization. Moscow: HSE Publishing House.

27.Fenn, R.K., 1978. Toward a theory of secularization. Monograph series - Society for the Scientific Study of Religion. 1. 91.

28. Global Christianity - A Reportonthe Sizeand Distribution of the World's Christian Population, 2011. Pew Research Center. Retrieved from https://www.pewforum.org/2011/12/19/global-christianity-exec/

29. Jenkins, P., 2002. The Next Christendom: The Coming of Global Christianity. New York: Oxford University Press.

30. Martin, D., 1978. A General Theory of Secularization. Oxford: Blackwell Publishing.

31. Voas, D., Chaves, M., 2016. Is the United States a Counterexample to the Secularization Thesis? American Journal of Sociology, 121(5). 1517-1556.

Дзюбак, Р. Б. - аспірант кафедри філософії, Львівський національний університет імені Івана Франка (Львів, Україна) 
E-mail:roman.dziubak@yahoo.com,

ORCID iD: https://orcid.org/0000-0002-6321-7739

\section{КОНЦЕПЦІї СЕКУЛЯРИЗАЦІї НА ТЛІ ГЛОБАЛЬНИХ ТРАНСФОРМАЦЙ РЕЛІГІЙНОГО ЛАНДШАФТУ СУЧАСНОСТІ}

Анотація. Актуальність дослідження зумовлена тим фактом, що секуляризація залишається основною тенденцією релігійної динаміки країн Глобальної Півночі, що постає контрастом на тлі високих показників релігійності країн Глобального Півдня. У світлі нещодавніх досліджень секуляризації у США набуває актуальності теза про кореляцію між високими показниками соціально-економічного розвитку та секуляризацією. У зв'язку з цим, виникає потреба перегляду даної тези, по-перше, у світлі нових результатів досліджень, по-друге, в контексті попередніх соціально-антропологічних та соціологічних способів осмислення секуляризації. Мета статті - аналіз кореляції між показниками соціально-економічного розвитку та показниками секуляризації у контексті глобальних трансформацій релігійного ландшафту сучасності. Завдання дослідження: 1) розглянути основні релігійні тенденції Глобальної Півночі та Глобального Півдня; 2) проаналізувати відношення між секуляризацією та модернізацією в контексті основних соціологічних теорій релігійної динаміки; 3) оцінити існуючі перспективи на взаємозв'язок секуляризації та модернізації на тлі глобальної релігійної ситуації сьогодення; 4) окреслити напрями подальших теоретичних розробок теми відношення між показниками соціальноекономічного розвитку та секуляризації. Наукова новизна дослідження полягає у тому, що вперше у вітчизняному контексті зроблена спроба аналізу основних висновків дослідження Д. Воаза та М. Чавеса під назвою "Чи Сполучені Штати є контрприкладом до теорії секуляризації?" у контексті дискурсу на тему секуляризації. Висновки - теза про кореляцію між високими показниками секуляризації та соціально-економічного розвитку країн сьогодні розглядається вченими насамперед, як тенденція, а не як певного роду неминучий соціальний закон. Подальше дослідження причин та характеру секуляризації вимагає комплексного підходу, який, по-перше, враховував би тенденцію до зниження релігійності у розвинених країнах у зв'язку з підвищенням екзистенційної безпеки, подруге, зважав би на історичні, культурні та релігійні особливості конкретних регіонів, а по третє, брав до уваги діалектичну взаємодію світських та релігійних дієвців.

Ключові слова: секуляризація, дехристиянізація, християнство, модернізація, комплексний підхід.

Дзюбак, Р. Б. - аспирант кафедры философии, Львовский национальный университет имени Ивана Франко (Львов, Украина)

E-mail: roman.dziubak@yahoo.com,

ORCID iD: https://orcid.org/0000-0002-6321-7739

\section{КОНЦЕПЦИИ СЕКУЛЯРИЗАЦИИ НА ФОНЕ ГЛОБАЛЬНЫХ ТРАНСФОРМАЦИЙ РЕЛИГИОЗНОГО ЛАНДШАФТА СОВРЕМЕННОСТИ}

Аннотация. Актуальность исследования обусловлена тем фактом, что секуляризация является основной тенденцией религиозной динамики стран Глобального Севера, что выделяться на фоне высоких показателей религиозности стран Глобального Юга. В свете недавних исследований секуляризации в США актуальность сегодня обретает тезис о корреляции между высокими показателями социально-экономического развития и секуляризацией. В связи с этим возникает необходимость пересмотра данного тезиса, вопервых, в свете новых результатов исследований, во-вторых, в контексте предыдущих Концепції секуляризації на тлі глобальних трансформацій релігійного ландшафту сучасності 
социально-антропологических и социологических способов осмысления секуляризации. Цель статьи - анализ корреляции между показателями социально-экономического развития и показателями секуляризации в контексте глобальных трансформаций религиозного ландшафта современности. Задачи исследования: 1) рассмотреть основные религиозные тенденции Глобального Севера и Глобального Юга; 2) проанализировать отношение между секуляризацией и модернизацией в контексте основных социологических теорий религиозной динамики; 3) оценить существующие перспективы взаимосвязи секуляризации и модернизации на фоне нынешней религиозной ситуации стран Глобального Севера; 4) обозначить направления дальнейших теоретических разработок темы соотношения показателей социально-экономического развития и секуляризации. Научная новизна исследования заключается том, что впервые в украинском контексте предпринята попытка анализа основных выводов исследования Д. Воаза и М. Чавеса под названием "Являются ли Соединенные Штаты контрпримером к теории секуляризации?" в контексте общего дискурса на тему секуляризации. Выводы корреляция между высокими показателями секуляризации и социально-экономического развития стран рассматривается сегодня учеными прежде всего как тенденция, а не как определенного рода неизбежный социальный закон. Дальнейшее исследование причин и характера секуляризации требует комплексного подхода, который, во-первых, учитывал бы тенденцию к снижению религиозности в развитых странах в связи с повышением экзистенциальной безопасности, во-вторых, принимал во внимание исторические, культурные и религиозные особенности конкретных регионов, а в-третьих, учитывал диалектическое взаимодействие светских и религиозных участников социальной жизни.

Ключевые слова: секуляризация, дехристианизация, христианство, модернизация, комплексный подход.

Received date 10.01.2020

Accepted date 15.01.2020

Published date 25.01.2020 